\title{
Intake and digestion of non-traditional feedstuffs by farmed collared peccary (Mammalia, Tayassuidae)
}

\author{
Sérgio Luiz Gama Nogueira-Filho ${ }^{1,2^{*}}$ (iD), Karen Martins ${ }^{1}$, Rogério Martins Borges ${ }^{1}$, \\ Alcester Mendes ${ }^{1}$, Selene Siqueira da Cunha Nogueira ${ }^{1,2}$, Jérôme Bindelle ${ }^{3}$
}

\footnotetext{
${ }^{1}$ Universidade Estadual de Santa Cruz, Laboratório de Nutrição de Animais Neotropicais, Ilhéus, BA, Brasil.

${ }^{2}$ Instituto Nacional de Ciência e Tecnologia em Estudos Interdisciplinares e Transdiciplinares em Ecologia e Evolução, Salvador, BA, Brasil.

${ }^{3}$ University of Liege, Gembloux Agro-Bio Tech, Animal Science Unit, Gembloux, Belgium.
}

\begin{abstract}
To assess the ability of the collared peccary (Pecari tajacu) to digest dietary fiber, four adult male collared peccaries were randomly assigned to a $4 \times 4$ Latin square design to determine the effects of feeding non-traditional feed ingredients, taken from palm trees with different levels of dietary fiber, on intake and coefficient of total tract apparent digestibility (CTTAD) and mean retention time. Four experimental diets were provided ad libitum: corn and soybean meal-based control diet; corn and palm kernel cake-based diet; corn and peach palm byproduct-based diet; and hay, palm kernel cake, and peach palm byproductbased diet. The CTTAD of neutral detergent fiber and acid detergent fiber (ADF) were $0.80 \pm 0.09$ and $0.61 \pm 0.21$, respectively. Increasing levels of ADF in diets also linearly decreased the CTTAD of crude protein and gross energy, while increasing non-fiber carbohydrate linearly decreased the CTTAD of ADF. These results confirm the ability of peccaries to digest fiber. However, the intake of a high-moisture and lignified ingredient, as the peach palm byproduct, decreased feed intake of peccaries due to their relatively small forestomach volume, which in turn may decrease their performance when used for prolonged periods. Despite of that, collared peccary gain a significant benefit in digestibility of dietary fiber due to its complex stomach in which fermentation occurs.
\end{abstract}

Key Words: digestive physiology, feed evaluation, fiber, wild animal

\section{Introduction}

Agroindustrial byproducts cause environmental pollution if not used as animal feeds. The industrial production of the heart of peach palm (Bactris gasipaes) provides 40 tons per day of byproduct at a single processing plant (Cabral et al., 2015), while the palm oil industry yields $40 \mathrm{~kg}$ per ha of palm kernel cake (PKC) (Devendra, 2006). Peach palm byproducts and PKC are mainly used in ruminant diets, owing to their high fiber content (Wan Zahari and Alimon, 2005; Cabral et al., 2015). Their high availability and low prices have also stimulated their use in the farming of collared peccary (Pecari tajacu), a piglike mammal under domestication in Brazil and other Neotropical countries (Nogueira and Nogueira-Filho, 2011). Although a non-ruminant, the collared peccary has

Received: November 7, 2017

Accepted: April 26, 2018

*Corresponding author: slgnogue@uesc.br

Copyright (c) 2018 Sociedade Brasileira de Zootecnia. This is an Open Access article distributed under the terms of the Creative Commons Attribution License (http://creativecommons.org/licenses/by/4.0/), which permits unrestricted use, distribution, and reproduction in any medium, provided the original work is properly cited. a forestomach displaying active microbial fermentation (Sowls, 1997).

Schwarm et al. (2010) hypothesized that the relatively small volume of the forestomach, which leads to lower fermentative capacity than in other foregut fermenters, explains the low digestibility coefficients of dietary fiber for collared peccary determined by Shively et al. (1985) and Elston et al. (2005). In contrast, Comizzoli et al. (1997) and Nogueira-Filho (2005) recorded relatively high digestibility coefficients of dietary fiber for collared peccary fed ground diets. Hence, the ability of collared peccary to ferment dietary fiber remains controversial. However, dietary fiber covers a wide range of plant polysaccharides and lignin that are resistant to hydrolysis by digestive secretions of the animals, such as non-starch polysaccharides, oligosaccharides, and resistant starch (Bindelle et al., 2008). Not all fiber components are readily fermented by the microbiota of the animal, and, with their specific digestive tract, collared peccary might be able to degrade some fiber components more extensively than others. The extent of fiber fermentation will depend on the trade-offs among fermentability of the different fiber fractions, feed intake levels, and passage time in the digestive tract, and the effect might be diet-specific. 
Therefore, an experiment was performed to measure the coefficient of total-tract apparent digestibility (CTTAD) and to explore the links with the mean retention time and feed intake of collared peccary fed a corn-based concentrate diet. This diet was supplemented with different proportions of palm kernel cake and peach palm byproduct, two palm industry byproducts that have contrasting total fiber content and nature, mainly the high-moisture and lignin contents of the peach palm byproduct.

\section{Material and Methods}

This study was conducted in Ilhéus, Bahia, Brazil

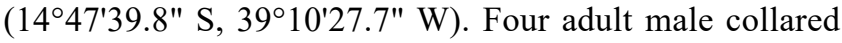
peccaries, aged from 24 to 36 months, with an average initial body mass of $21.8+0.5 \mathrm{~kg}$, were used. They were selected according to their body mass and docile temperament. After being weighed and dewormed, the animals were housed in individual $11.3-\mathrm{m}^{2}(7.5 \times 1.5 \mathrm{~m})$ pens. Each pen was divided into two sections: one covered area of $3.0 \mathrm{~m}^{2}$ - named the metabolism pen - had a wooden lattice suspended floor that allowed the feces and urine to be collected separately; and an additional area, comprised of a partially sheltered section and a "solarium" section, which allows unobstructed exposure to natural sunlight, with a cement floor (Figure 1), as previously described by Borges et al. (2017). The protocol for this experiment followed Brazilian laws and was approved by the local Ethics Committee on Animal Use (CEUA) (case no. 33).

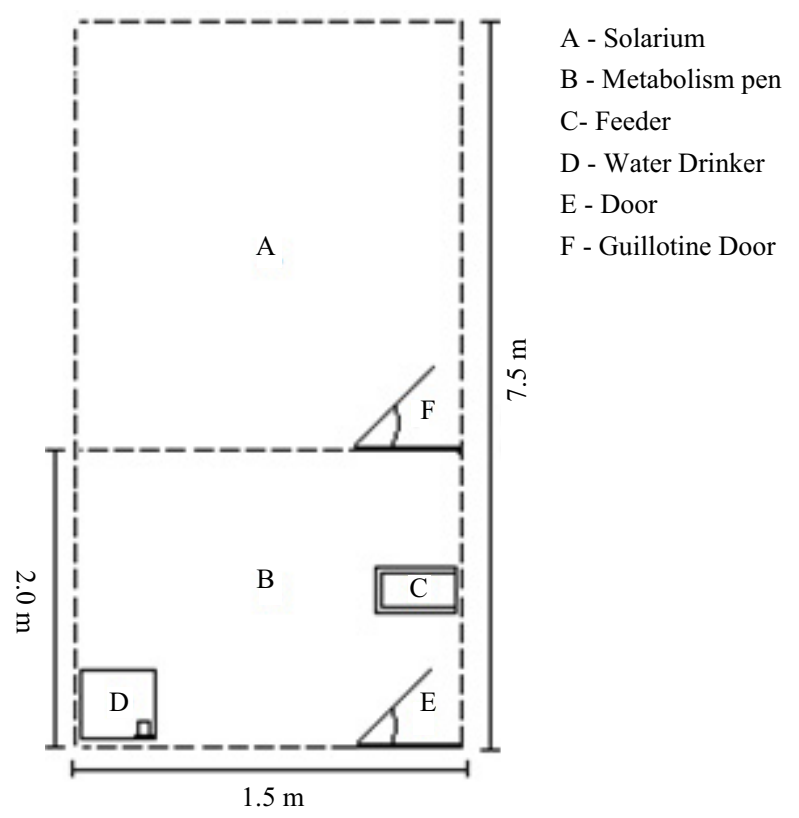

Figure 1 - Schematic drawing of the pen - metabolism pen and solarium - used during the experiment.
After 30 days of adaptation to the experimental housing conditions, peccaries were weighed once again and randomly ascribed to one of the four experimental diets in a $4 \times 4$ Latin square design, to determine the effects of dietary fiber provided by non-traditional feedstuffs on intake and CTTAD of nutrients and energy by the collared peccary. Peccaries were fed one of four experimental diets: control grain corn and soybean meal-based diet; PKC - grain corn roughly mixed with ground palm kernel cake-based diet; FPP - grain corn mixed into the peach palm byproductbased diet; and MIX - chopped hay, ground palm kernel cake mixed into the chopped peach palm byproduct-based diet (Table 1). The inclusion levels of byproducts were established based on the results reported by NogueiraFilho (2005), which verified a decrease in the digestibility of nutrients when collared peccary received a diet with levels above $281 \mathrm{~g}$ NDF kg$^{-1}$ dry matter (DM), $142 \mathrm{~g}$ acid detergent fiber (ADF) $\mathrm{kg}^{-1} \mathrm{DM}$, and $56 \mathrm{~g}$ lignin $\mathrm{kg}^{-1} \mathrm{DM}$.

All animals had ad libitum access to food until the next meal was offered. The daily feed intake was calculated by taking the difference between the amount of diet offered and the refused leftovers weighed on the next day. We checked for the evaporation losses during $24 \mathrm{~h}$ in the feeding trough by using extra dishes outside the pens. After 15 days of adaptation to the diets (Nogueira-Filho, 2005), peccaries were maintained in the metabolism pens, and fecal and urine collections were carried out for five consecutive days. Animals were individually weighed with a minimum of disturbance before and after each experimental period.

At the end of the adaptation period, the animals underwent a fasting period of $16 \mathrm{~h}$. They were subsequently fed, at 8:00 h, $50 \%$ of the daily amount reached at the end of the adaptation period of the same diets mixed with $20 \mathrm{~g} \mathrm{~kg}^{-1}$ titanium dioxide $\left(\mathrm{TiO}_{2}\right)$, used as a dietary marker for the determination of the mean retention time. By adopting the restriction of fasting and diet, all food was consumed. When the meal was over, the animals had ad libitum access to food until the next meal was offered at 8:00 h on all the following collection days. All voided feces were collected, and the time of individual defecations was recorded during the day. Feces voided at night were treated as one defecation unit, and an average time between the last check in the evening and the first check in the morning was calculated. Collection lasted up to $120 \mathrm{~h}$ after the labeled meal was provided, trying to assure a maximum excretion of the total $\mathrm{TiO}_{2}$ that had been consumed. Individual fecal collections were weighed and thoroughly mixed, and a subsample was taken for the determination of DM and marker concentrations. The remains from each collection 
over the five-day period were kept in frozen storage, before they were pooled, for each animal, to be used for subsequent analysis.

Diets, feces, and feed residue samples were thawed to room temperature and dried to constant mass at $65{ }^{\circ} \mathrm{C}$. The dried samples were ground through a $1.0-\mathrm{mm}$ mesh screen in a laboratory mill. Samples were analyzed for their contents in DM by drying at $105^{\circ} \mathrm{C}$ for $24 \mathrm{~h}$ (method 967.03; AOAC, 1990); in ash, by burning at $550^{\circ} \mathrm{C}$ for $8 \mathrm{~h}$ (method 923.03; AOAC, 1990); ether extract (EE), by using Soxhlet apparatus and petroleum ether (AOAC 920.39); in $\mathrm{N}$, according to the Kjeldahl method and calculating the crude protein $(\mathrm{CP})$ content $(\mathrm{N} \times 6.25$; method 981.10; AOAC, 1990); and in gross energy, by means of an adiabatic oxygen bomb calorimeter (1241 Adiabatic Calorimeter, PARR Instrument Co., Illinois, USA). The concentration in neutral detergent fiber (NDF) and ADF was determined as described by Van Soest et al. (1991) for NDF with the use of sodium sulfite and heat stable $\alpha$-amylase. Both NDF and ADF contents were expressed exclusive of residual ash. Lignin was extracted with $720 \mathrm{~mL} \mathrm{~L}^{-1}$ sulfuric acid (Robertson and Van Soest, 1981). Hemicellulose (HEM) was estimated as NDF minus ADF, and cellulose (CEL) as ADF minus lignin (Table 1).

Non-fibrous carbohydrates (NFC) were calculated according to Hall (2000), following the Equation 1:

$\mathrm{NFC}=1000-[\mathrm{CP}+\mathrm{NDF}+\mathrm{EE}+\mathrm{ash}] \quad$ (Equation 1)

The titanium dioxide concentration in feces samples was determined according to the method described by Myers et al. (2004). Briefly, the feces samples underwent mineralization in sulfuric acid at $420{ }^{\circ} \mathrm{C}$ in the presence of a Ti-free Kjeldahl catalyst, and the Ti concentration ( $\mathrm{mg} \mathrm{g}^{-1}$ $\mathrm{DM}$ of feces) was determined spectrophotometrically after conversion with $\mathrm{H}_{2} \mathrm{O}_{2}$. As the defecation rate was quite variable among animals, feces samples were pooled every $12 \mathrm{~h}$ for determination of the titanium dioxide concentration.

Table 1 - Proportions of ingredients offered, chemical compositions $\left(\mathrm{g} \mathrm{kg}^{-1}\right.$ dry matter, unless stated) of consumed diets (mean \pm standard deviation), and chemical composition of ingredients

\begin{tabular}{|c|c|c|c|c|c|}
\hline Ingredient & Control & $\mathrm{PKC}$ & FPP & MIX & \\
\hline Ground corn & 900 & 940 & 320 & - & \\
\hline Soybean meal & 78 & - & - & - & \\
\hline Palm kernel cake & - & 38 & - & 30 & \\
\hline Fresh peach palm byproduct & - & - & 658 & 848 & \\
\hline Grass hay & - & - & - & 100 & \\
\hline Vitamin-mineral mix ${ }^{1}$ & 12 & 12 & 12 & 12 & \\
\hline Mineral salt ${ }^{2}$ & 10 & 10 & 10 & 10 & \\
\hline Total (kg) & 1.0 & 1.0 & 1.0 & 1.0 & \\
\hline \multicolumn{6}{|l|}{ Chemical composition of diets consumed } \\
\hline Dry matter & $909( \pm 27)$ & $909( \pm 30)$ & $374( \pm 16)$ & $221( \pm 14)$ & \\
\hline Crude protein & $95( \pm 6)$ & $84( \pm 7)$ & $79( \pm 8)$ & $75( \pm 12)$ & \\
\hline Non-fibrous carbohydrates & $601( \pm 17)$ & $615( \pm 12)$ & $289( \pm 23)$ & $161( \pm 8)$ & \\
\hline Neutral detergent fiber & $264( \pm 14)$ & $153( \pm 11)$ & $342( \pm 25)$ & $677( \pm 19)$ & \\
\hline Acid detergent fiber & $63( \pm 3)$ & $54( \pm 12)$ & $232( \pm 28)$ & $445( \pm 32)$ & \\
\hline Hemicellulose & $75( \pm 7)$ & $79( \pm 8)$ & $141( \pm 33)$ & $192( \pm 30)$ & \\
\hline Cellulose & $51( \pm 4)$ & $58( \pm 7)$ & $254( \pm 13)$ & $345( \pm 21)$ & \\
\hline Lignin & $10( \pm 2)$ & $11( \pm 2)$ & $66( \pm 17)$ & $88( \pm 12)$ & \\
\hline Gross energy $\left(\mathrm{MJ} \mathrm{kg}^{-1}\right)$ & $19.7( \pm 0.4)$ & $18.3( \pm 1.2)$ & $16.9( \pm 2.7)$ & $16.1( \pm 1.3)$ & \\
\hline Chemical composition of ingredients & Ground corn & Soybean meal & Palm kernel cake & Peach palm & Grass hay \\
\hline Dry matter & 930 & 923 & 924 & 118 & 938 \\
\hline Crude protein & 83 & 456 & 161 & 80 & 23 \\
\hline Non-fibrous carbohydrates & 649 & 221 & 124 & 161 & 204 \\
\hline Ether extract & 41 & 18 & 107 & 61 & 8 \\
\hline Neutral detergent fiber & 140 & 154 & 563 & 632 & 721 \\
\hline Acid detergent fiber & 59 & 130 & 487 & 458 & 422 \\
\hline Hemicellulose & 81 & 24 & 76 & 174 & 299 \\
\hline Cellulose & 29 & 118 & 375 & 363 & 357 \\
\hline Lignin & 10 & 10 & 42 & 95 & 65 \\
\hline Gross energy $\left(\mathrm{MJ} \mathrm{kg}^{-1}\right)$ & 17.8 & 20.8 & 20.1 & 15.9 & 14.8 \\
\hline
\end{tabular}

Control: corn and soybean meal-based control diet; PKC: corn and palm kernel cake-based diet; FPP: corn and peach palm byproduct-based diet; MIX: hay, palm kernel cake and peach palm byproduct-based diet.

${ }_{1}^{1}$ Vitamin-mineral premix provided per kilogram of complete diet: vitamin A, 6,000 IU; vitamin D3, $900 \mathrm{IU}$; vitamin E, $15.00 \mathrm{IU}$; vitamin $\mathrm{K} 3,2.60 \mathrm{mg}$; vitamin B1, 2.00 mg; vitamin B2, $6.00 \mathrm{mg}$; vitamin B6, $2.00 \mathrm{mg}$; vitamin B12, $10.00 \mathrm{mcg}$; niacin, $30.00 \mathrm{mg}$; pantothenic acid, $17.00 \mathrm{mg}$; folic acid, $1.00 \mathrm{mg}$; biotin, $0.03 \mathrm{mg}$; choline, $300 \mathrm{mg}$; iron, $160.0 \mathrm{mg}$; zinc, $160.0 \mathrm{mg}$; cupper, $16.0 \mathrm{mg}$; iodine, $0.30 \mathrm{mg}$; manganese, $4.0 \mathrm{mg}$; selenium, $0.30 \mathrm{mg}$.

${ }^{2}$ Mineral salt formulated for use in beef cattle feeding with levels of assurance $\left(\mathrm{kg}^{-1}\right)$ : Ca, $167 \mathrm{~g}$; and $\mathrm{P}, 130 \mathrm{~g}$. 
The CTTAD of nutrients and energy was determined by the differences between the amount of nutrients and gross energy ingested and the amount excreted as: ( $g$ of nutrient or energy in $-g$ of nutrient or energy out $) /(g$ of nutrient or energy in).

Titanium dioxide excretion curves based on fecal $\mathrm{TiO}_{2}$ concentrations measured at the different time points were modelled by fitting to a gamma function (Equation 2) using the lscurvefit function of MatLab R2013a (Mathworks, Natick, MA, USA). Mean retention time (MRT) calculated from the parameters of the fitted model (Equation 3) as described in Thielemans et al. (1978):

$C(t)=a\left(t-t_{0}\right)^{b} \mathrm{e}^{-c\left(t-t_{0}\right)}$,

(Equation 2)

$\operatorname{MRT}=\frac{(b+1)}{c}+t_{0}$,

(Equation 3)

in which $C(t)$ is the $\mathrm{TiO}_{2}$ marker concentration in the sample; $t$ is the time interval after marker administration; $t_{0}$ is the minimum time required to record marker excretion; and $a, b$, and $c$ are parameters allowing a fitting of the excretion curves.

Each individual animal was used as an experimental unit. Data of body mass change, CTTAD, and MRT were compared using General Linear Models (GLM), including animal and period as random effect and diet as a fixed effect, followed by Tukey post-hoc test, when appropriate, by means of Statistica 7.0 (StatSoft, Inc. 1984-2004). Pearson correlations between digestible nutrients and energy intake and their CTTAD were also calculated using the same software. Then, the effect of the level of dietary fiber on the CTTAD of energy of the collared peccary was analyzed and expressed by regression between individual values of CTTAD with the daily intake of NDF per $\mathrm{kg}$ of metabolic weight $\left(\mathrm{g} \mathrm{kg}^{-0.75}\right)$ or ADF $\left(\mathrm{g} \mathrm{kg}^{-0.75}\right)$, using the same software. The same procedure was used for the determination of the effect of the daily intake of NDF or ADF per $\mathrm{kg}$ of metabolic weight $\left(\mathrm{g} \mathrm{kg}^{-0.75}\right)$ on the CTTAD of crude protein and the effect of the daily intake of non-fibrous carbohydrates (NFC; $\mathrm{g} \mathrm{kg}^{-0.75}$ ) on the CTTAD of ADF and NDF. Prior to all analyses, the Lilliefors test was applied to test the normal distribution of data, using Statistica 7.0 (StatSoft, Inc. 1984-2004). In all statistical tests, a P-value $<0.05$ was considered significant.

\section{Results}

In general, we did not observe any behavior indicative of stress while animals were restrained inside the metabolism pens. Even though peccaries appeared to feed selectively, the chemical composition of the leftovers did not differ from the diets offered. Moreover, we recorded lower voluntary daily dry matter intakes when peccaries were fed peach palm byproduct (FPP and MIX diets) (Table 2). This resulted in lower daily intakes of digestible protein and digestible energy (Table 2). Despite this fact, no consistent differences were observed in daily body mass changes among diets (Table 2).

The CTTAD of ADF and cellulose were lower in the control diet, while CTTAD of gross energy was lower when collared peccary were fed the MIX diet (Table 3 ). We verified a linear decrease in the apparent digestibility of crude protein (ADCP), along with the increase in the intake of ADF ( $\mathrm{g}$ ) per $\mathrm{kg}$ of metabolic weight (ADFi; $\mathrm{g} \mathrm{kg}^{-0.75}$ ), according to the equation 4 :

$\mathrm{ADCP}=0.97-0.12 \mathrm{ADFi}\left(\mathrm{R}^{2}=0.35 ; \mathrm{F}=7.58 ; \mathrm{P}=0.020\right)$

(Equation 4)

There was also a linear decrease in the apparent digestibility of energy (ADE) with the increase of ADFi $\mathrm{g} \mathrm{kg}^{-0.75}$ according to the equation 5:

$\mathrm{ADE}=1.01-0.09 \mathrm{ADFi}\left(\mathrm{R}^{2}=0.23 ; \mathrm{F}=0.23 ; \mathrm{P}=0.048\right)$

(Equation 5)

Table 2 - Daily means ( \pm SD) of body mass (BM) change, fresh feed intake, dry matter (DM) intake, and intake in dry matter basis of nutrients by collared peccaries fed four experimental diets

\begin{tabular}{|c|c|c|c|c|c|}
\hline & Control & PKC & FPP & MIX & P-value \\
\hline BM change $\left(\mathrm{g} \mathrm{day}^{-1}\right)$ & $-45.0( \pm 58.5)$ & $61.8( \pm 32.0)$ & $-98.2( \pm 104.1)$ & $7.1( \pm 90.7)$ & 0.06 \\
\hline Fresh feed $\left(\mathrm{g} \mathrm{kg}^{-0.75}\right)^{1}$ & $36.8( \pm 3.2) \mathrm{a}$ & $33.9( \pm 1.0) \mathrm{a}$ & $37.2( \pm 1.8) \mathrm{a}$ & $22.7( \pm 2.4) b$ & 0.003 \\
\hline Dry matter $\left(\mathrm{g} \mathrm{kg}^{-0.75}\right)$ & $33.5( \pm 2.1) \mathrm{a}$ & $26.3( \pm 0.8) b$ & $12.5( \pm 0.7) \mathrm{c}$ & $6.1( \pm 1.0) \mathrm{d}$ & 0.0001 \\
\hline Digestible energy $\left(\mathrm{kJ} \mathrm{kg}^{-0.75}\right)$ & $561( \pm 34) a$ & $425( \pm 10) b$ & $178( \pm 10) \mathrm{c}$ & $62( \pm 8) d$ & 0.0001 \\
\hline Digestible protein $\left(\mathrm{g} \mathrm{kg}^{-0.75}\right)$ & $2.6( \pm 0.1) \mathrm{a}$ & $1.7( \pm 0.1) b$ & $0.7( \pm 0.0) \mathrm{c}$ & $0.2( \pm 0.0) \mathrm{d}$ & 0.0001 \\
\hline $\mathrm{NFC}\left(\mathrm{g} \mathrm{kg}^{-1} \mathrm{BM}\right)^{2}$ & $8.3( \pm 1.7) a$ & $8.3( \pm 0.5) \mathrm{a}$ & $2.7( \pm 0.5) b$ & $0.4( \pm 0.2) \mathrm{c}$ & 0.0001 \\
\hline $\mathrm{NDF}\left(\mathrm{g} \mathrm{kg}^{-1} \mathrm{BM}\right)$ & $4.0( \pm 0.8) \mathrm{a}$ & $1.9( \pm 0.1) b$ & $1.9( \pm 0.4) b$ & $2.1( \pm 1.0) b$ & 0.0008 \\
\hline $\mathrm{ADF}\left(\mathrm{g} \mathrm{kg}^{-1} \mathrm{BM}\right)$ & $0.9( \pm 0.2) \mathrm{abc}$ & $0.7( \pm 0.0) b$ & $1.3( \pm 0.2) \mathrm{c}$ & $1.3( \pm 0.7) \mathrm{c}$ & 0.002 \\
\hline
\end{tabular}

NFC - non-fibrous carbohydrates; NDF - neutral detergent fiber; ADF - acid detergent fiber; PKC - palm kernel cake.

Control: no fresh peach palm byproduct and PKC; PKC: $38 \mathrm{~g} \mathrm{~kg}^{-1} \mathrm{DM}$ palm kernel cake; FPP: $658 \mathrm{~g} \mathrm{~kg}^{-1} \mathrm{DM}$ fresh peach palm byproduct; $\mathrm{MIX}$ : a mixture of $30 \mathrm{~g}$ kg $\mathrm{g}^{-1} \mathrm{DM}$ palm kernel cake and $848 \mathrm{~g} \mathrm{~kg}^{-1} \mathrm{DM}$ fresh peach palm byproduct.

${ }^{1} \mathrm{~g} \mathrm{~kg}^{-0.75}$ : intake $(\mathrm{g})$ per $\mathrm{kg}$ of metabolic weight.

${ }^{2} \mathrm{~g} \mathrm{~kg}^{-1} \mathrm{BM}$ : intake (g) per $\mathrm{kg}$ of body mass.

Means $( \pm$ standard deviation) within a row $(\mathrm{a}, \mathrm{b}$, and $\mathrm{c})$ with no different letters differ $(\mathrm{P}<0.05)$. 
We also verified a linear decrease in the digestibility of ADF (DADF), along with the increase in the intake of NFC (NFCi; $\mathrm{g} \mathrm{kg}^{-0.75}$ ), according to the equation 6 :

$\mathrm{DADF}=0.85-0.02 \mathrm{NFCi}\left(\mathrm{R}^{2}=0.47 ; \mathrm{F}=12.34 ; \mathrm{P}=0.030\right)$

(Equation 6)

There was, however, no effect of the NFCi on the apparent digestibility of $\mathrm{NDF}\left(\mathrm{R}^{2}=0.05 ; \mathrm{F}=0.74 ; \mathrm{P}>0.05\right)$. There were also no effects of the NDF intake on the apparent digestibility of crude protein $\left(\mathrm{R}^{2}=0.04 ; \mathrm{F}=0.67\right.$; $\mathrm{P}>0.05$ ). There was a large variation between diets for average mean retention times (Figure 2). Moreover, owing to their content in fiber with higher water holding capacity, feces from peccaries fed PKC, FPP, and MIX displayed higher moisture content diluting the marker compared with the control diet (Figure 2).

The statistical model did not show differences between diets (Table 3). Moreover, the marker was not completely

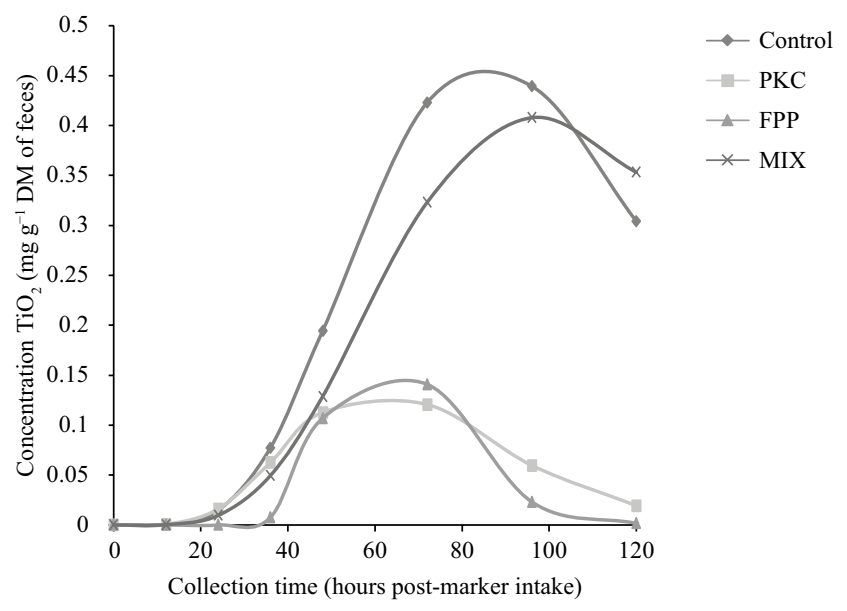

Control: corn and soybean meal-based control diet; PKC: corn and palm kernel cakebased diet; FPP: corn and peach palm byproduct-based diet; MIX: hay, palm kernel cake, and peach palm byproduct-based diet.

Figure 2 - Concentration of $\mathrm{TiO}_{2}$ marker in the feces of the peccary number 2 after feeding at time 0 one of four different diets. excreted after $120 \mathrm{~h}$; the average recovery (\%) ranged from $76.8( \pm 7.3) \%$ for the control diet to $86.8( \pm 6.7) \%$ for the MIX diet (Table 3).

\section{Discussion}

We performed this study to check the ability of collared peccary to digest dietary fiber and to evaluate the possibility of including fiber-rich agricultural byproducts in its diet. The digestibility values of NDF and ADF recorded in the present study are like those determined by Comizzoli et al. (1997) and Nogueira-Filho (2005) for collared peccaries fed diets with similar levels of dietary fiber. Higher values observed in the present study for the CTTAD of cell wall contents than those found by Shively et al. (1985) could be explained by a difference in the age of animals used in the experiments. In ruminants and in pigs, an increment in microbiota colonization with age has been reported in terms of diversity, as well as total population (Rey et al., 2014; Niu et al., 2015). Adult animals, as used in the present study, show higher digestive efficiency than young ones (Barboza et al., 2009). The obtained results, therefore, corroborated the proposition of Comizzoli et al. (1997), who stated that an adaptation of the digestive capacity, especially regarding fiber fermentation, occurs with age in the peccary, as it does in other species of mammals (Le Goff and Noblet, 2001).

In turn, Elston et al. (2005) compared collared peccaries with wild pigs (Sus scrofa) and stated that the digestibility of fiber in peccaries is not higher than in monogastric suids. In this previous study, however, collared peccaries and wild pigs were fed a commercial diet with moderate concentrations of fiber (383 $\mathrm{g} \mathrm{NDF} \mathrm{kg}^{-1} \mathrm{DM}$ and $265 \mathrm{~g}$ $\left.\mathrm{ADF} \mathrm{kg}^{-1} \mathrm{DM}\right)$. It is possible to assume that such a diet had high levels of soluble carbohydrates. High levels of soluble carbohydrates decrease the digestibility of dietary

Table 3 - Means ( \pm standard deviation) of the coefficient of total tract apparent digestibility (CTTAD) of nutrients and mean retention time (MRT) by collared peccaries fed four experimental diets

\begin{tabular}{|c|c|c|c|c|c|}
\hline CTTAD & Control & PKC & FPP & MIX & P-value \\
\hline Dry matter & $0.93( \pm 0.02) \mathrm{a}$ & $0.91( \pm 0.03) \mathrm{a}$ & $0.66( \pm 0.08) b$ & $0.70( \pm 0.04) b$ & 0.00002 \\
\hline Crude protein & $0.81( \pm 0.03) \mathrm{a}$ & $0.79( \pm 0.01) \mathrm{ab}$ & $0.74( \pm 0.01) \mathrm{ab}$ & $0.44( \pm 0.06) b$ & 0.00001 \\
\hline Gross energy & $0.88( \pm 0.01) \mathrm{a}$ & $0.88( \pm 0.02) \mathrm{a}$ & $0.88( \pm 0.02) \mathrm{a}$ & $0.60( \pm 0.04) b$ & 0.00001 \\
\hline NFC & $0.98( \pm 0.01)$ & $0.99( \pm 0.01)$ & $0.91( \pm 0.01)$ & $0.82( \pm 0.01)$ & 0.02 \\
\hline $\mathrm{NDF}$ & $0.71( \pm 0.05) \mathrm{ab}$ & $0.62( \pm 0.12) \mathrm{a}$ & $0.78( \pm 0.05) b$ & $0.67( \pm 0.03) \mathrm{ab}$ & 0.03 \\
\hline $\mathrm{ADF}$ & $0.38( \pm 0.10) \mathrm{a}$ & $0.66( \pm 0.09) \mathrm{b}$ & $0.87( \pm 0.03) \mathrm{c}$ & $0.76( \pm 0.02) b c$ & 0.00001 \\
\hline Hemicellulose & $0.78( \pm 0.08) a$ & $0.61( \pm 0.15) \mathrm{ab}$ & $0.58( \pm 0.11) \mathrm{ab}$ & $0.48( \pm 0.11) b$ & 0.01 \\
\hline Cellulose & $0.17( \pm 0.06) \mathrm{a}$ & $0.55( \pm 0.16) b$ & $0.89( \pm 0.03) \mathrm{c}$ & $0.68( \pm 0.08) b$ & 0.0001 \\
\hline MRT (h) & $81.4( \pm 10.20)$ & $64.8( \pm 10.73)$ & $64.1( \pm 9.94)$ & $83.3( \pm 19.65)$ & 0.09 \\
\hline
\end{tabular}

NFC - non-fibrous carbohydrates; NDF - neutral detergent fiber; ADF - acid detergent fiber.

Control: corn and soybean meal-based control diet; PKC: corn and palm kernel cake-based diet; FPP: corn and peach palm byproduct-based diet; MIX: hay, palm kernel cake, and peach palm byproduct-based diet.

Means ( \pm standard deviation) within a row $(\mathrm{a}, \mathrm{b}$, and $\mathrm{c})$ with different letters differ $(\mathrm{P}<0.05)$ 
fiber in ruminants (Van Soest, 1994). The same effect was verified in the present study by the decrease in digestibility of ADF with the increase in the intake of non-cell-wall carbohydrates by peccaries. Therefore, the high level of soluble carbohydrates in commercial pig feed formulae probably explains the low digestibility of cell-wall contents by the collared peccary described by Elston et al. (2005). An additional factor that explains the low digestibility of fiber in peccaries was the high degree of fiber lignification in the diet tested by Elston et al. (2005).

Collared peccaries in this study showed digestibility of dietary fiber comparatively higher than that of wild and domestic pigs. To make these comparisons, we only used data of species receiving diets with similar levels of dietary fiber. For instance, the CTTAD of 0.62-0.71 for NDF and 0.38-0.66 for ADF for collared peccaries fed control and PKC diets (fiber levels of 138-152 $\mathrm{g} \mathrm{NDF} \mathrm{kg}^{-1} \mathrm{DM}$ and 63-74 $\mathrm{g} \mathrm{kg}^{-1}$ ADF DM) were comparatively higher than the ones reported for the river hog (Potamochoerus porcus), warty pig (Sus cebifrons), and babirusa (Babyrousa babyrussa). These three species of wild pigs achieved CTTAD of 0.41-0.63 and 0.04-0.25 for NDF and ADF, respectively, when fed mixed diets with fiber levels of 173-257 $\mathrm{g} \mathrm{NDF} \mathrm{kg}^{-1} \mathrm{DM}$ and of 51-76 $\mathrm{g} \mathrm{ADF} \mathrm{kg}^{-1} \mathrm{DM}$ (Clauss et al., 2008). In turn, domestic pigs showed mean CTTAD of 0.47 and 0.37 for NDF and ADF, respectively, when fed diets with $140 \mathrm{~g} \mathrm{NDF} \mathrm{kg}^{-1} \mathrm{DM}$ and $62 \mathrm{~g} \mathrm{ADF} \mathrm{kg}^{-1}$ DM (Noblet and Perez, 1993).

We verified a lower voluntary dry matter intake of the FPP and MIX diets, which were mainly composed of fresh peach palm byproduct. A possible explanation for the low intake of diets with fresh peach palm byproduct may be the relatively high levels of lignified fibrous material of this ingredient. Previously, Comizzoli et al. (1997) also recorded poor intake of high lignified, ground hay by peccaries. Furthermore, the low voluntary intake of these diets resulted in daily intakes of digestible energy and nitrogen below the requirements of the species, estimated at $420 \mathrm{~kJ}$ digestible energy per kg-0.75 (Comizzoli et al., 1997) and $0.815 \mathrm{~g} \mathrm{~N} \mathrm{~kg}^{-0.75}$ (Carl and Brown, 1985). In addition, the fresh peach palm byproduct has a comparatively high water content that results in low energy concentration. Therefore, the relatively small volume of the forestomach of peccaries compared with that of other foregut fermenters (Langer, 1978) means that the species can hardly meet its energy requirements when consuming diets with low energy concentration, in a similar manner to the monogastric domestic pig (Leterme et al., 2010).

The digestive capability of peccaries is heavily impacted by feed intake, as was verified by testing two diets that contain over $90 \%$ DM compared with two diets that have between 22 and $37 \%$ DM. The digestibility results obtained in the present study could be affected by these different intakes of DM alone. Therefore, the low voluntary intake of high-moisture feedstuffs, such as the peach palm byproduct, can decrease the performance of peccaries during their long-term use in farm conditions, because the intake of digestible energy and digestive protein falls below the requirements of the species.

The high variability between peccaries probably explains the lack of difference between diets for average MRT. Moreover, the MRT determined in our study (73.4 \pm 9.0$)$ was higher than the MRT of $35 \mathrm{~h}$ for collared peccaries fed rabbit concentrate, green vegetables, and fruits (Schwarm et al., 2009). In a previous study, Schwarm et al. (2009) recorded an average voluntary intake of $53 \mathrm{~g} \mathrm{~kg}^{-0.75}$ day $^{-1}$, which was much higher than the dry matter intake recorded in this study. Therefore, the relatively high MRT determined in the present study can be explained by the relatively low voluntary intake in the present study. Despite this consideration, as digestion is a time-dependent process, the relatively high MRT determined in the present study shows the ability of the forestomach of peccaries to slow down the passage of ingesta through their gut. One must consider that the length of the sample collection period was not enough to allow total recovery of the marker. Therefore, further study must be done to properly evaluate the effect of different levels of dietary fiber on digesta passage of the collared peccary.

\section{Conclusions}

The collared peccary can digest dietary fiber. The inclusion of high levels of soluble carbohydrates decreases this ability. Moreover, the intake of high-moisture ingredients decreases the feed intake of peccary due to its relatively small forestomach volume.

\section{Acknowledgments}

We thank Prof. Marcus Clauss, for his pertinent and valuable comments, which helped to improve the original manuscript. The authors thank the staff at the Neo-tropical Animal Nutrition Laboratory (NeoNutLab), for animal care and management of peccaries during feeding trials. This study was funded by the Conselho Nacional de Desenvolvimento Científico e Tecnológico (Process \# 303589/2015-9; 305428/2012-8, and 478315/2), Coordenação de Aperfeiçoamento de Pessoal de Nível Superior (CAPES/WBI \#021/14 and Process 
\#88881.119854/2016-0), Instituto Nacional de Ciência e Tecnologia em Estudos Interdisciplinares e Transdisciplinares em Ecologia e Evolução (IN-TREE - Process \#465767/2014-1), and Wallonie Bruxelles International - Wallonie Bruxelles International/CAPES/ WBI \# 021/1.

\section{References}

AOAC - Association of Official Analytical Chemistry. 1990. Official methods of analysis. 15th ed. AOAC International, Arlington, VA.

Barboza, P. S.; Parker, K. L. and Hume, I. D. 2009. Integrative wildlife nutrition. Springer, Berlim.

Bindelle, J.; Leterme, P. and Buldgen, A. 2008. Nutritional and environmental consequences of dietary fibre in pig nutrition: a review. BASE 12:69-80.

Borges, R.; Mendes, A.; Nogueira, S. S. C.; Jérôme, B. and Nogueira-Filho, S. L. G. 2017. Protein requirements of collared peccary (Pecari tajacu). Tropical Animal Health and Production 49:1353-1359. https://doi.org/10.1007/s11250-017-1333-5

Cabral, I. S.; Azevêdo, J. A. G.; Almeida, F. M.; Pereira, L. G. R.; Araújo, G. G. L.; Nogueira, A. S.; Lins, S. L.; Oliveira, G. A. and Oliveira Filho, C. A. A. 2015. Silage or fresh by-product of peach palm as roughage in the feeding of lambs. Tropical Animal Health and Production 47:525-531. https://doi.org/10.1007/ s11250-015-0756-0

Carl, G. R. and Brown, R. B. 1985. Protein requirement of adult collared peccaries. Journal of Wildlife Management 49:351-355.

Clauss, M.; Nijboer, J.; Loermans, J. H. M.; Roth, T.; Kuilen, J. and Beynen, A. C. 2008. Comparative digestion studies in wild suids at Rotterdam Zoo. Zoo Biology 27:305-319.

Comizzoli, P.; Peiniau, J.; Dutertre, C.; Planquette, P. E. and Aumaitre, A. 1997. Digestive utilization of concentrated and fibrous diets by two peccary species (Tayassu peccari, Tayassu tajacu) raised in French Guyana. Animal Feed Science and Technology 64:215-226.

Devendra, C. 2006. Strategies for intensive use of local feedstuffs for large-scale economic beef production in Malaysia. p.21-24. In: Proceedings of the 2nd International Conference on Animal Nutrition; Malacca, Malaysia.

Elston, J. J.; Klinksiek, E. A. and Hewitt, D. G. 2005. Digestive efficiency of collared peccaries and wild pigs. The Southwestern Naturalist 50:515-519. https://doi.org/10.1894/0038-4909(2005) 050[0515:DEOCPA $] 2.0 . C O ; 2$

Hall, M. B. 2000. Neutral detergent soluble carbohydrates nutritional relevance and analysis: a laboratory manual. University of Florida, Gainesville, FL.

Langer, P. 1978. Anatomy of the stomach of the collared peccary, Dicotyles tajacu (L., 1758) (Artiodactyla: Mammalia). Zeitschrift für Säugetierkunde 43:42-59.

Le Goff, G. and Noblet, J. 2001. Comparative total tract digestibility of dietary energy and nutrients in growing pigs and adult sows. Journal of Animal Science 79:2418-2427.

Leterme, P.; Londoño, A. M.; Ordoñez, D. C.; Rosalesa, A.; Estrada, F.; Bindelle, J. and Buldgen, A. 2010. Nutritional value and intake of aquatic ferns (Azolla filiculoides Lam. and Salvinia molesta Mitchell.) in sows. Animal Feed Science and Technology 155:55-64. https://doi.org/10.1016/j.anifeedsci.2009.10.002

Myers, W. D.; Ludden, P. A. and Nayigihugu, V. 2004. Technical Note: A procedure for the preparation and quantitative analysis of samples for titanium dioxide. Journal of Animal Science $82: 179-183$

Niu, Q.; Li, P.; Hao, S.; Zhang, Y.; Kim, S. W.; Li, H.; Ma, X.; Gao, S.; He, L.; Wu, W. J.; Huang, X.; Hua, J.; Zhou, B. and Huang, R. 2015. Dynamic distribution of the gut microbiota and the relationship with apparent crude fiber digestibility and growth stages in pigs. Scientific Reports 5:9938.

Noblet, J.; Perez, J. M. 1993. Prediction of digestibility of nutrients and energy values of pig diets from chemical analysis. Journal of Animal Science 71:3389-3398.

Nogueira, S. S. C. and Nogueira-Filho, S. L. G. 2011. Wildlife farming: an alternative to unsustainable hunting and deforestation in Neotropical forests? Biodiversity and Conservation 20:1385-1397. https://doi.org/10.1007/s10531-011-0047-7

Nogueira-Filho, S. L. G. 2005. The effects of increasing levels of roughage on coefficients of nutrient digestibility in the collared peccary (Tayassu tajacu). Animal Feed Science and Technology 120:151-157. https://doi.org/10.1016/j.anifeedsci.2004.12.010

Rey, M.; Enjalbert, F.; Combes, S.; Cauquil, L.; Bouchez, O. and Monteils, V. 2014. Establishment of ruminal bacterial community in dairy calves from birth to weaning is sequential. Journal of Applied Microbiology 116:245-257. https://doi.org/10.1111/jam.12405

Robertson, J. B. and Van Soest, P. J. 1981. The analysis of dietary fiber in food. p.123-158. In: The detergent system of analysis and its application to human foods. James, W. P. T. and Theander, O., eds. Marcel Dekker, New York, NY.

Schwarm, A.; Ortmann, S.; Rietschel, W.; Kühne, R.; Wibbelt, G. and Clauss, M. 2010. Function, size and form of the gastrointestinal tract of the collared Pecari tajacu (Linnaeus 1758) and white-lipped peccary Tayassu pecari (Link 1795). European Journal of Wildlife Research 56:569-576. https://doi.org/10.1007/s10344-009-0348-2

Schwarm, A.; Ortmann, S.; Wolf, C.; Streich, W. J. and Clauss, M. 2009. Passage marker excretion in red kangaroo (Macropus rufus), collared peccary (Pecari tajacu) and colobine monkeys (Colobus angolensis, C. polykomos, Trachypithecus johnii). Journal of Experimental Zoology Part A. Ecological Genetics and Phisiology 311:647-661. https://doi.org/10.1002/jez.552

Shively, C. L.; Whiting, F. M.; Swingle, R. S.; Brown, W. H. and Sowls, L. K. 1985. Some aspects of the nutritional biology of the collared peccary. Journal of Wildlife Management 49:729-732.

Sowls, L. K. 1997. Javelinas and other peccaries. Texas A\&M University Press, College Station, Texas.

Thielemans, M. F.; Francois, E.; Bodart, C.; Thewis, A.; Dupont, F.; Lallemand, L.; and Malburny, C. 1978. Mesure du transit gastrointestinal chez le porc a l'aide des radiolanthanides: comparaison avec le mouton. Annales de Biologie Animale Biochimie Biophysique 18:237-247.

Van Soest, P. J. 1994. Nutritional ecology of the ruminants. Cornell University Press, Ithaca, New York.

Van Soest, P. J.; Robertson, J. B. and Lewis, B. A. 1991. Methods for dietary fiber, neutral detergent fiber, and non-starch polysaccharides in relation to animal nutrition. Journal of Dairy Research 74:3583-3597.

Wan Zahari, M. and Alimon, A. R. 2005. Use of oil palm kernel cake and oil palm by-products in compound feed. Palm Oil Developments 40:5-9. 